\title{
Implementasi Sistem Peramalan Persediaan Barang Menggunakan Metode Moving Average
}

\author{
Wulandari \\ Fakultas Teknologi Informasi, Sistem Informasi, Universitas Budi Luhur, Jakarta, Indonesia \\ Email: wulandari@budiluhur.ac.id \\ Email Penulis Korespondensi: wulandari@budiluhur.ac.id
}

\begin{abstract}
Abstrak-PT. XYZ adalah perusahaan yang bergerak dalam bidang penjualan obat dan vitamin hewan ternak, setiap periodenya Jumlah permintaan barang selalu terjadi perubahan. Masalah yang dihadapi PT. XYZ yaitu barang kadaluarsa dikarenakan pada periode tertentu jumlah stok menumpuk karena jumlah permintaan sedikit yang mengakibatkan perusahaan menjadi rugi. Tujuan dari penelitian ini adalah melakukan peramalan untuk proses persediaan barang agar meminimalisis kerugian perusahaan terhadap perkiraan yang dilakukan selama ini. Guna meminimalisir permasalahan tersebut, penulis memodelkan sistem informasi peramalan(forecasting) pengadaan barang menggunakan VB.Net dan MYSQL serta menggabungkan metode Moving Average. Metode yang digunakan yaitu dengan pengumpulan dan pengolahan data, dan dilanjukan dengan proses analisa data, untuk memodelkan kebutuhan sistem penulis menggunakan UML. Hasil akhir dari penelitian ini yaitu nilai akurasi mencapai $88 \%$ sehingga sistem peramalan persediaan barang menggunakan metode moving average dapat membantu manager dalam pengambilan keputusan untuk menentukan proses persediaan barang dimasa yang akan datang.
\end{abstract}

Kata Kunci: Forecasting, Persediaan Barang, Moving Average, Implementasi Sistem

\begin{abstract}
PT. XYZ is a company engaged in the sale of drugs and vitamins for livestock, each period the number of requests for goods always changes. Problems faced by PT. XYZ, which is expired goods because in a certain period the amount of stock is piling up due to the small amount of demand that causes the company to lose. The purpose of this study is to forecast the inventory process in order to minimize the company's losses against the estimates made so far. In order to minimize these problems, the authors model the forecasting information system for procurement of goods using VB.Net and MYSQL and combine the Moving Average method. The method used is the data collection and processing, and continued with the data analysis process, to model the system requirements of the writer using UML. The final result of this study is that the value of accuracy reaches $88 \%$ so that the inventory forecasting system using the moving average method can help managers in making decisions to determine the process of inventory in the future.
\end{abstract}

Keywords: Forecasting, Inventory, Moving Average, System Implementation

\section{PENDAHULUAN}

Informasi merupakan hal yang sangat penting dan berharga bagi sebuah perusahaan, karena dengan adanya informasi yang tepat dan akurat dapat digunakan manager untuk pertimbangan dalam penambilan keputusan dimasa yang akan datang [1][2]. Saat ini hampir semua bidang usaha, jasa, instansi, institusi dan organisasi sudah beralih menggunakan teknologi, peralihan kegiatan administrasi yang semula masih manual menjadi sangatlah penting, selain dapat membantu meringankan pekerjaan [3]. Salah satunya kegiatan persediaan barang yang dilakukan oleh PT. XYZ yang bergerak dalam bidang penjualan obat-obatan dan vitamin hewan ternak yang tersebar di wilayah Indonesia. Permintaan produk yang tidak pasti disetiap periodenya mengharuskan perusahaan ini untuk dapat menganalisa dengan tepat permintaan di periode yang akan datang[2]. Masalah yang dihadapi adalah jumlah stok barang yang tersedia masih banyak sedangkan jumlah permintaan sedikit sehingga menyebabkan barang menjadi kadaluarsa

Persediaan adalah bahan atau barang yang disimpan untuk digunakan memenuhi kebutuhan tertentu, misalnya digunakan dalam proses produksi atau untuk dijual kembali[4]. Sebagai salah satu asset penting dalam sebuah perusahaan, pengendalian terhadap persediaan barang merupakan suatu kegiatan penting yang mendapat perhatian khusus dari perusahaan, Tujuan utama dalam pengendalian persediaan adalah untuk menjaga tingkat persediaan suatu barang pada tingkat yang optimal sehingga dapat memperoleh penghematan [5].

Dalam mentukan jumlah persediaan barang setiap bulannya dibutuhkan data lama untuk mengetahuai atau memperkirakan jumlah persediaan barang, kegiatan untuk mengetahui atau memperkirakan apa yang akan terjadi pada masa yang akan datang disebut dengan peramalan[6]. Menurut Subagyo forecasting(peramalan) adalah peramalan (perkiraan) mengenai sesuatu yang belum terjadi [7]. Definisi lain dari peramalan adalah metode untuk memperkirakan suatu nilai di masa depan dengan menggunakan data masa lalu dan juga diartikan sebagai seni dan ilmu untuk memperkirakan kejadian pada masa yang akan datang sedangkan aktivitas peramalan merupakan fungsi bisnis yang berusaha memperkirakan penjualan dan penggunaan suatu produk sehingga produk-produk itu dapat dibuat dalam kuantitas yang tepat[4]. Untuk itu perlu dibuatkan sistem peramalan persediaan barang yang nantinya hasil dari proses peramalan tersebut dapat digunakan untuk menganalisa jumlah persediaan barang dimasa yang akan datang. Metode yang digunakan dalam penelitian ini adalah metode Moving Average.

Penelitian sebelumnya yang dilakukan oleh D. Anggoro and Wulandari adalah meramalkan penjualan obat ternak dimasa yang akan datang menggunakan metode moving average, data yang digunakan dalam penelitian tersebut adalah data dalam kurun waktu 5 tahun terakhir yang terdiri dari data training tahun 2015-2018 sedangkan 
JURNAL MEDIA INFORMATIKA BUDIDARMA

Volume 4, Nomor 3, Juli 2020, Page 707-714

ISSN 2614-5278 (media cetak), ISSN 2548-8368 (media online)

Available Online at https://ejurnal.stmik-budidarma.ac.id/index.php/mib

DOI 10.30865/mib.v4i3.2199

data testing adalah data tahun 2019, parameter yang digunakan dalam penelitian tersebut adalah kategori dan wilayah.

Penelitian serupa yang pernah dilakukan oleh R. Y. Hayuningtyas, dalam penelitian tersebut menggabungkan metode weighted moving average dan metode double exponential smoothing, data yang digunakan untuk penelitian ini yaitu data penjualan selama satu tahun 2016. Dalam penelitian tersebut dijelaskan perbandingan hasil peramalan menggunakan kedua metode, hasil peramalan persediaan untuk periode berikutnya 52 dengan Weighted Moving Average dan 60 dengan Double Exponential Smoothing. Kedua metode ini memiliki nilai Mean Square Error. Dimana nilai error Weighted Moving Average yaitu 0,114 dan nilai error Mean Square Error 6,12, nilai error terkecil [8].

Sedangkan penelitian yang dilakukan oleh Hendriani dkk, dalam penelitiannya dilakukan peramalan untuk menentukan jumlah kebutuhan obat yang tidak pasti di masa mendatang dengan menggunakan metode Weight Moving Average (WMA) dan untuk membantu menentukan batas aman persediaan digunakan metode Reorder Point(ROP), sehingga sistem peramalan ini dapat memperoleh nilai ramalan yang baik dengan nilai akurasi kebenaran sebesar 70\% [4], tujuanya yaitu terhindar dari masalah stockout dan overstock.

Penelitian lain dilakukan Haryanto Tanuwijaya, dalam penelitianya menggabungkan metode winter's exponential smoothing dan single moving average untuk menentukan kebutuhan pemakaian obat dan merencanakan pengadaan obat dengan lebih tepat. Hasil menunjukkan bahwa $61,9 \%$ obat RS memiliki pola data bersifat stationer sehingga lebih tepat menggunakan metode SMA. Sedangkan 38,1\% obat sisanya memiliki pola data bersifat musiman sehingga lebih tepat menggunakan metode WES [9].

\section{METODOLOGI PENELITIAN}

Dalam menyelesaikan penelitian ini dibuat tahapan penelitian yang ditunjukan pada gambar 1 dibawah ini:

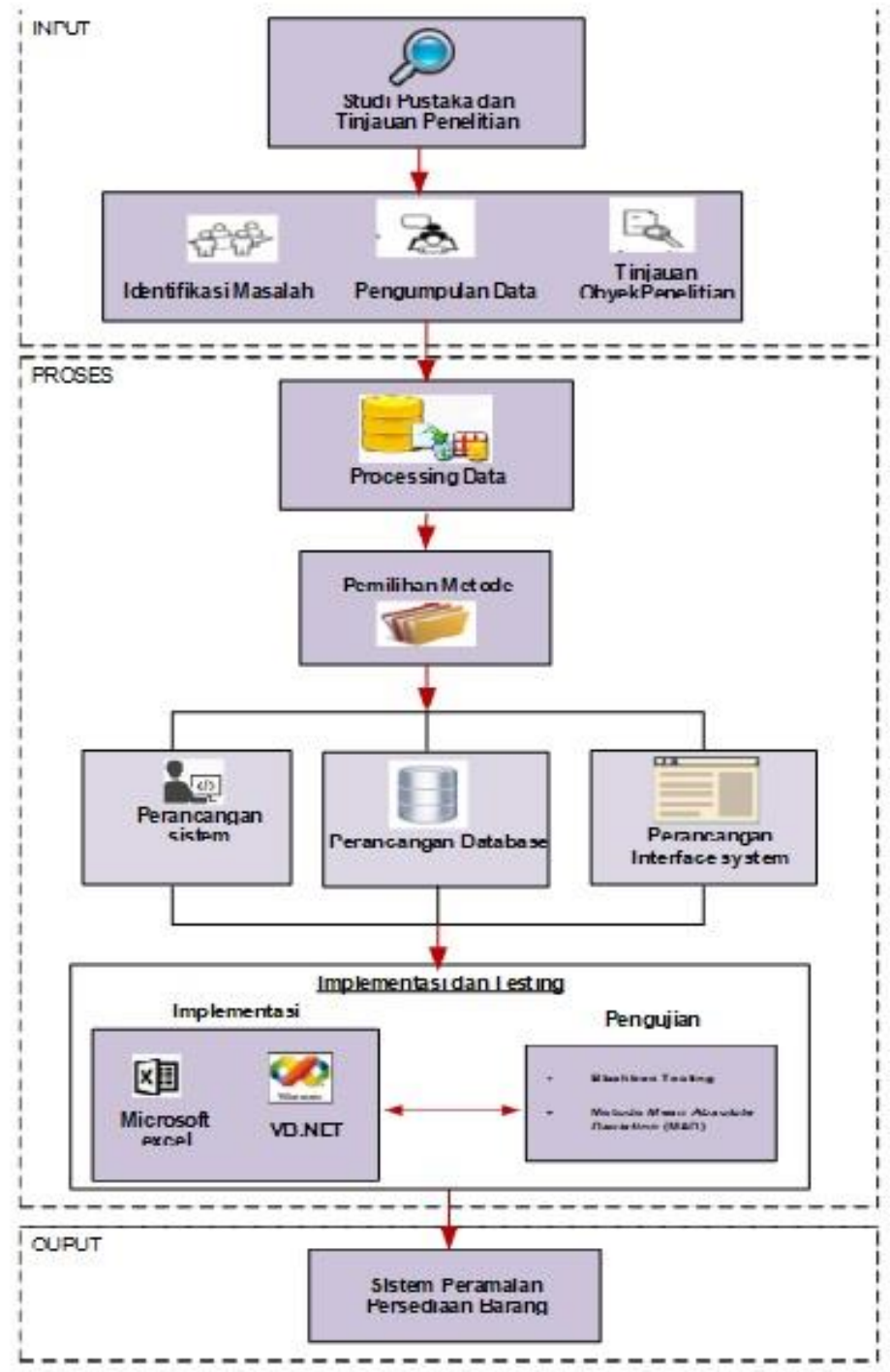

Gambar 1. Langkah-Langkah Penelitian 
a) Studi Pustaka

Membaca dan mempelajari literature-literatur terdahulu yang ada kaitanya dengan penelitian yang diambil penulis.

b) Identifikasi Masalah

Menganalisis permasalahan dan sistem yang sedang berjalan, dengan wawancara langsung ke bagian terkait.

c) Pengumpulan Data

Mengambil sample data masa lalu, diambil 1 tahun terakhir data penjualan barang pada tahun 2018, dari data tersebut dibagi menjadi 2 kategori yaitu: Pertama data training yaitu data tahun 2018 yang digunakan untuk mengembangkan metode yang dipilih. Kedua data testing yaitu data tahun 2019 yang digunakan untuk testing hasil dari peramalan.

d) Tinjauan Obyek Penelitian

Penulis memilih obyek yang diteliti yaitu perusahaan yang bergerk dalam bidang penjualan obat dan Vitamin sebagai tempat riset.

e) Prosesing Data

Setelah data terkumpul data olah dengan mensortir atau mengecek data dalam bentuk Microsoft Excel untuk menghindari duplikasi data sekaligus menghilangkan reudancy. Setelah format data sesuai maka data selanjutnya data dianalisa menggunakan metode yang dipilih.

f) Pemilihan Metode

Metode yang digunakan dalam penelitian ini adalah Moving Average. Metode Moving Average merupakan model dalam melakukan peramalan teknik ini digunakan dalam memprediksi permintaan dengan cara melakukan perhitungan nilai rata-rata dari nilai permintaan sesungguhnya dari sejumlah periode yang spesifik sebelumnya. Setiap peramalan baru ditetapkan pada periode yang lama dan digantikan dengan permintaan dari periode yang baru, sehingga data pada perhitungan berpindah sepanjang waktu sesuai dengan namanya Moving Average [1].

g) Perancangan Sistem

Dalam proses perancangan sistem penulis menggunakan UML(Unified Modelling Language) yaitu Bahasa pemodelan untuk sistem atau perangkat lunak yang berparadigma berorientasi objek. Pemodelan (modeling) sesungguhnya digunakan untuk penyederhanaan permasalahan yang kompleks sehingga lebih mudah untuk dipelajari dan dipahami [10]. Komponen tersebut yaitu Activity Diagram, Use Case Diagram, Squeence Diagram, Entity Relationship Diagram(ERD).

h) Perancangan Database

Pada tahapan perancangan database penulis menggunakan E-R Diagram untuk dapat memahami pola hubungan antar data dengan lebih jelas. Dan dilanjutkan dengan pembuatan basis data menggunakan database Mysql yaitu salah satu jenis database server yang sangat terkenal. Mysql termasuk jenis RDBMS( Rational Database management System)[11].

i) Perancangan Interface system

Dalam tahapan perancangan interface penulis merancang dengan konsep easy to use, agar pengguna dapat memanfaatkan dengan mudah.

j) Implementasi

Dalam Proses Implementasi, penulis menggunakan Microsoft excel utuk mengolah data dan menggunakan Bahasa pemrograman VB.NET untuk pengkodean atau (coding) yang dikoneksikan dengan database Mysql. VB.NET merupakan suatu perangkat lunak yang dapat digunakan untuk pengembangan berbagai macam aplikasi yang memiliki berbagai macam tipe antara lain aplikasi desktop (windows form,command line (console)), aplikasi web, windows mobile (Pocket PC)" [12].

k) Pengujian

Dalam tahapan pengujian dibagi menjadi 2 yaitu Pengujian program yaitu menggunkaan Blackbox testing dan pengujian Nilai Error menggunakan MAD(Mean Absolute Deviation ). MAD menrupakan pengujian dengan ketentuan semakin kecil nilai MAD menunjukan error yang dihasilkan semakin sedikit [13].

1) Hasil dari pengujian tersebut akan digunakan managemen sebagai pengambilan keputusan untuk proses persediaan barang di perusahaan.

\section{HASIL DAN PEMBAHASAN}

\subsection{Pengumpulan dan Pengolahan Data}

Dibawah ini merupakan data penjualan barang pada tahun 2018 yang dikumpulkan, kemudian data diolah dengan cara mensortir atau mengecek data dalam bentuk Microsoft Excel untuk menghindari duplikasi/reudancy data. Data akumulasi penjualan barang tahun 2018 ditunjukan pada tabel 1 dibawah ini: 
JURNAL MEDIA INFORMATIKA BUDIDARMA

Volume 4, Nomor 3, Juli 2020, Page 707-714

ISSN 2614-5278 (media cetak), ISSN 2548-8368 (media online)

Available Online at https://ejurnal.stmik-budidarma.ac.id/index.php/mib

DOI 10.30865/mib.v4i3.2199

Tabel 1. Data Penjualan barang tahun 2018

\subsection{Analisa Data}

\begin{tabular}{lrr}
\hline \multicolumn{1}{c}{ Bulan } & \multicolumn{1}{c}{ Tahun } & \multicolumn{1}{c}{ Qty(kg) } \\
\hline Januari & 2018 & 2826 \\
Februari & 2018 & 1905 \\
Maret & 2018 & 3753 \\
April & 2018 & 2250 \\
Mei & 2018 & 1828 \\
Juni & 2018 & 2070 \\
Juli & 2018 & 2510 \\
Agustus & 2018 & 1892 \\
September & 2018 & 2050 \\
Oktober & 2018 & 2221 \\
Nopember & 2018 & 1785 \\
Desember & 2018 & 2300 \\
\hline
\end{tabular}

Berdasarkan data yang sudah diolah, selanjunya data dianalisa menggunakan metode Moving Average, yang ditunjukan pada persamaan $1[13]$ :

Keterangan

$$
\mathrm{S}_{\mathrm{t}+1}=\frac{\mathrm{X}_{\mathrm{t}}+X_{t-1}+\cdots \mathrm{X}_{t-n+1}}{\mathrm{n}}
$$

$\mathrm{S}_{\mathrm{t}+1}=$ Prediksi untuk periode $\mathrm{t}+1$

$\mathrm{n} \quad=$ Jumlah periode yang digunakan untuk menghitung moving average

$\mathrm{X}_{\mathrm{t}} \quad=$ Data periode $\mathrm{i}$

Untuk melakukan peramalan persedian barang periode yang akan datang yaitu januari 2019, maka dilakukan pengujian dengan menggunakan Metode Moving Average dengan periode bergerak 3 bulan . Berikut perhitungan peramalan persediaan barang Moving Average:

$$
\mathrm{MA}=(\mathrm{n} 1+\mathrm{n} 2+\mathrm{n} 3+\ldots) / \mathrm{n}
$$

Keterangan

MA = Moving Average

$\mathrm{n} 1=$ data periode pertama

$\mathrm{n} 2=$ data periode kedua

$\mathrm{n} 3=$ data periode ketiga dan seterusnya

$\mathrm{n}=$ jumlah periode rata-rata bergerak

$\mathrm{MA}_{2019}=(2050+2221+1785) / 3$

$\mathrm{MA}_{2019}=6056 / 3$

$\mathrm{MA}_{2019}=2018.666667$

Tabel 2. Hasil Peramalan Moving Average

\begin{tabular}{lcrr}
\hline \multicolumn{1}{c}{ Bulan } & Tahun & Terjual (n) & Perkiraan MA \\
\hline Januari & 2018 & 2826 & - \\
Februari & 2018 & 1905 & - \\
Maret & 2018 & 3753 & - \\
April & 2018 & 2250 & 2828 \\
Mei & 2018 & 1828 & 2636 \\
Juni & 2018 & 2070 & 2610.333333 \\
Juli & 2018 & 2510 & 2049.333333 \\
Agustus & 2018 & 1892 & 2136 \\
September & 2018 & 2050 & 2157.333333 \\
Oktober & 2018 & 2221 & 2150.666667 \\
Nopember & 2018 & 1785 & 2054.333333 \\
Desember & 2018 & 2300 & 2018.666667 \\
& & 27390 & 20640.66667 \\
\hline
\end{tabular}

Tabel 2 diatas menerangkan tentang perhitungan peramalan menggunakan metode I yang dilakukan dalam kurun waktu 3 bulan. 
JURNAL MEDIA INFORMATIKA BUDIDARMA

Volume 4, Nomor 3, Juli 2020, Page 707-714

ISSN 2614-5278 (media cetak), ISSN 2548-8368 (media online)

Available Online at https://ejurnal.stmik-budidarma.ac.id/index.php/mib

DOI 10.30865/mib.v4i3.2199

\subsection{Rancangan Sistem}

\section{a. Activity Diagram}

Activity Diagram sistem usulan digambarkan pada gambar 2 dibawah ini:

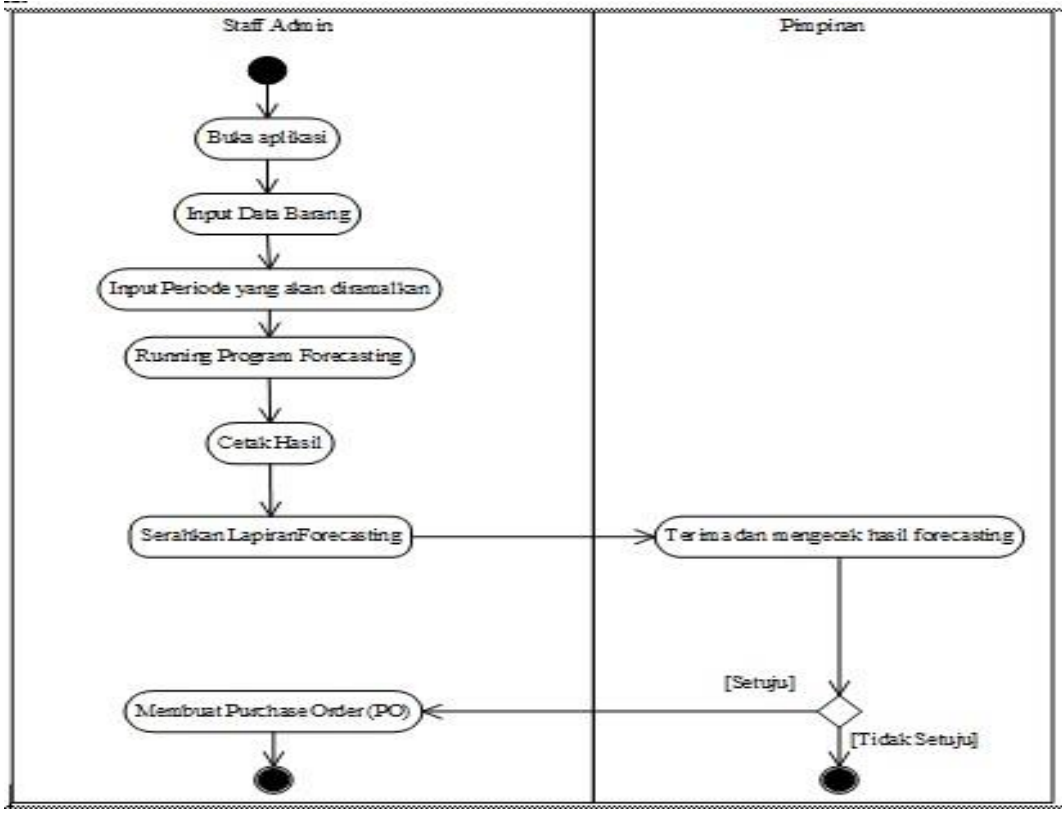

Gambar 2. Activity Diagram Proses Usulan

\section{b. Use Case Diagram}

Use Case diagram adalah merupakan gambaran interaksi antara sistem dengan pemakai (user). Dengan kata lain use case diagram dengan nyata menguraikan siapa yang akan menggunakan sistem dan dengan cara apa pemakai dapat saling berhubungan dengan sistem [14]. Gambar use case diagram transaksi ditunjukan pada gambar 3 dibawah ini:

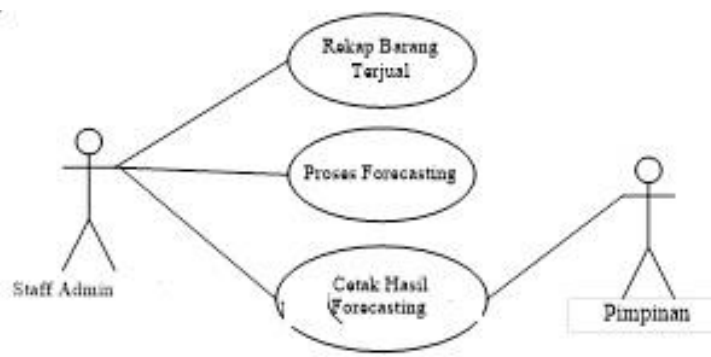

Gambar 3. Use Case Diagram Transaksi

\section{c. Class Diagram}

Class Diagram digunakan untuk membuat database dan memudahkan dalam membuat rancangan layar. Class Diagram untuk membuat sistem peramalan digambarkan pada gambar 4 berikut ini:

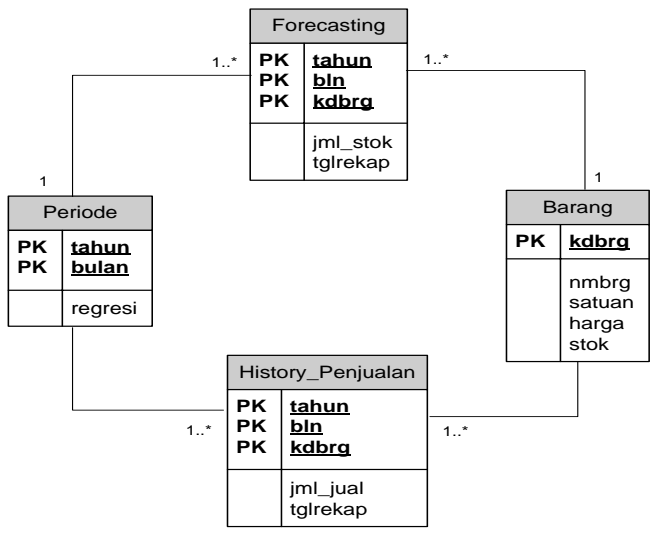

Gambar 4. Class Diagram persediaan barang 
JURNAL MEDIA INFORMATIKA BUDIDARMA

Volume 4, Nomor 3, Juli 2020, Page 707-714

ISSN 2614-5278 (media cetak), ISSN 2548-8368 (media online)

Available Online at https://ejurnal.stmik-budidarma.ac.id/index.php/mib

DOI 10.30865/mib.v4i3.2199

\section{d. Rancangan Layar}

Rancangan Layar menu utama terdiri dari File Master, Transaksi, Laporan dan Keluar. Rancangan menu utama digambarkan pada gambar 5 dibawah ini.

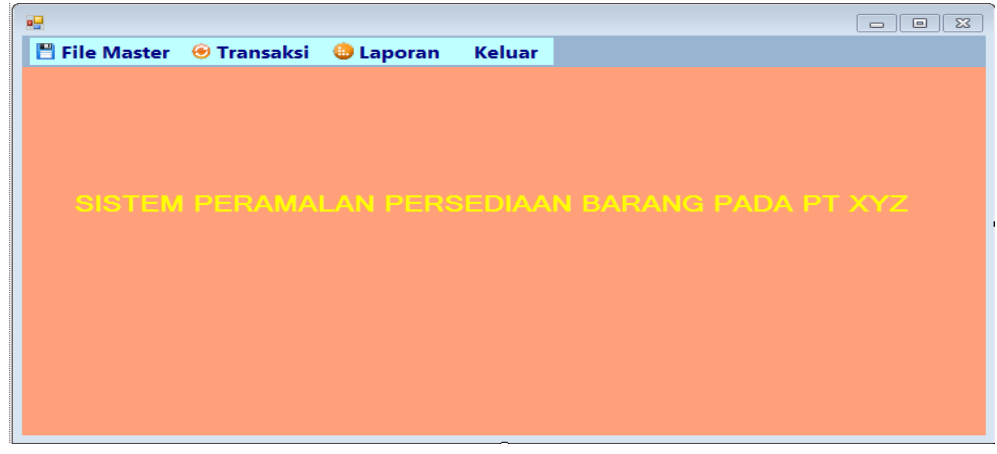

Gambar 5. Rancangan Menu Utama

Rancangan Master barang digunakan untuk menginput data barang. Rancangan master entry data barang ditunjukan pada gambar 6 berikut ini:

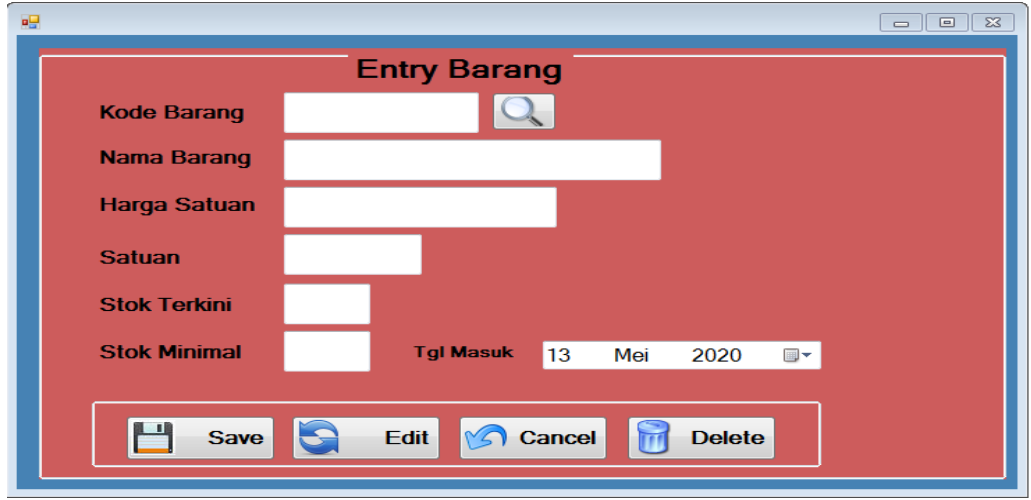

Gambar 6. Rancangan Menu Utama

Rancangan Layar transaksi proses peramalan digunakan untuk meramalkan data barang beberapa tahun kedepan dengan mengklik tombol PROSES. Rancangan layar proses peramalan data barang ditungjukan pada gambar 7 berikut ini:

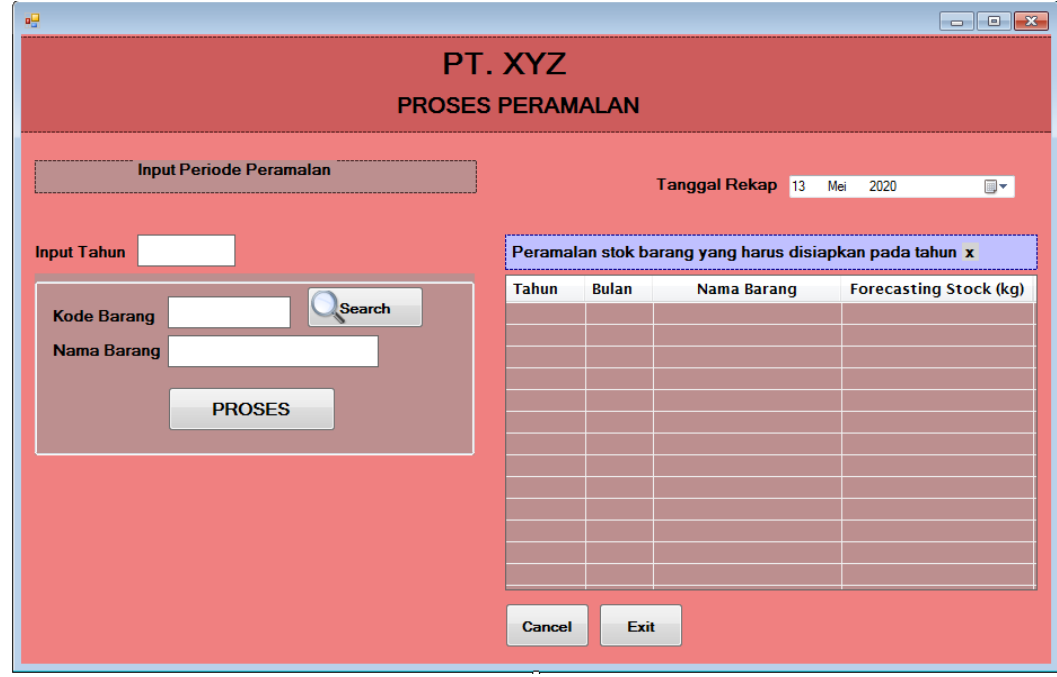

Gambar 7. Rancangan Layar Proses Forecasting

\subsection{Pengujian}

Pengujian yang dilakukan penulis dibagi menjadi 2 yaitu:

a. Pengujian Program 
Metode pengujian yang digunakan untuk pengujian mengunakan metode blackbox testing, yaitu melihat langsung code progam dan testing program dengan cara menginputkan data, jika data berhasil disimpan, berarti program berfungsi dengan baik, sedangkan jika program error maka akan dilakukan perbaikan sampai program berhasil simpan.

b. Pengujian Nilai Error

Sedangkan untuk pengujian nilai error pada proses peramalan pengadaan barang yaitu dengan menggunakan Deviasi Mutlak Rata-rata (MAD) yaitu nilai yang dihitung dengan mengambil jumlah nilai absolut dari setiap kesalahan peramalan dibagi dengan jumlah periode data (n). Berikut contoh perhitungan nilai error MAD (Mean Absolute Deviation):

Perhitungan data tahun 2018 ditunjukan pada persamaan 3 berikut ini:

$$
\text { MAD }=\frac{\text { Nilai Aktual-Nilai Permintaan }}{n}
$$

$$
\begin{aligned}
& =(2300-2018,67) / 12 \\
& =23,44
\end{aligned}
$$

Tabel 3. Hasil Perhitungan menggunakan MAD

\begin{tabular}{lcrrr}
\hline \multicolumn{1}{c}{ Bulan } & Tahun & Terjual (n) & MA & \multicolumn{1}{c}{ MAD } \\
\hline Januari & 2018 & 2826 & - & \\
Februari & 2018 & 1905 & - & \\
Maret & 2018 & 3753 & - & \\
April & 2018 & 2250 & 2828 & -48.16666667 \\
Mei & 2018 & 1828 & 2636 & -67.33333333 \\
Juni & 2018 & 2070 & 2610.333333 & -45.02777778 \\
Juli & 2018 & 2510 & 2049.333333 & 38.38888889 \\
Agustus & 2018 & 1892 & 2136 & -20.33333333 \\
September & 2018 & 2050 & 2157.333333 & -8.944444444 \\
Oktober & 2018 & 2221 & 2150.666667 & 5.86111111 \\
Nopember & 2018 & 1785 & 2054.333333 & -22.44444444 \\
Desember & 2018 & 2300 & 2018.666667 & 23.44444444 \\
\hline
\end{tabular}

Pada Tabel 3 diatas menunjukan hasil perhitungan nilai error MAD dalam kurun waktu 1 tahun/12 bulan, Nilai error tersebut didapatkan dari rumus persamaan 3 diatas sehingga didapatkan hasil nilai MAD Error 23,44 pada bulan desember 2018.

\section{KESIMPULAN}

Hasil perhitungan peramalan persediaan barang bulan januari 2019 menggunakan metode moving average adalah 2018.666667 atau 2019 kemudian dari hasil peramalan tersebut dilakukan pengujian menggunakan MAD(Mean Absolute Deviation) dan didapatkan hasil Nilai MAD Error 23,44 dengan tingkat akurasi dari perhitungan peramalan mencapai $88 \%$ yang didapat dari (nilai MA : nilai data aktual x 100\%). Dari hasil pengujian tersebut dapat ditarik kesimpulan bahwa dengan adanya sistem peramalan persediaan barang menggunakan metode moving average dapat digunakan sebagai sistem pengambilan keputusan bagi manager dalam menentukan jumlah persediaan barang untuk periode kedepanya. Penulis menyarankan untuk penelitian berikutnya menggunakan metode peramalan lain yang nilai akurasinya mendekati $100 \%$ dari nilai aktual dengan tujuan meminimalisir kerugian perusahaan akibat proses persediaan barang yang tidak akurat.

\section{REFERENCES}

[1] D. Anggoro And Wulandari, "Sistem Peramalan Permintaan Sebagai Penunjang Analisa Penjualan Obat Ternak," Pp. 420-426, 2019.

[2] D. Anggoro And Wulandari, "Forecasting Demand Dengan Metode Single Exponential Smoothing Untuk Analisa Jumlah Penjualan Obat Ternak," No. November, Pp. 1-10, 2019.

[3] L. Fajarita Et Al., "Penerapan Forecasting Stright Line Method Dalam Pengadaan Stok Barang Mendatang," Pp. 310 317, 2018.

[4] Hendriani Dkk, "Sistem Peramalan Persediaan Obat Dengan Metode Weight Moving Average Dan Reorder Point (Studi Kasus: Puskesmas Soropia)," Vol. 2, No. 2, Pp. 207-214, 2016.

[5] E. Herjanto, Manajemen Operasi, Edisi Keti. Jakarta: Grasindo, 2008.

[6] W. R. K. B. Siagian Dan Sugiarto, "Metode Moving Average Dan Metode Winter Dalam Peramalan,” Pp. 1-12, 2014.

[7] P. Subagyo, Forecasting Konsep Dan Aplikasi. Yogyakarta: Bpfe-Yogyakarta, 2013.

[8] R. Y. Hayuningtyas, "Peramalan Persediaan Barang Menggunakan Metode Weighted Moving Average Dan Metode Double Exponential," Vol. 13, No. 2, Pp. 217-222, 2017.

[9] H. Tanuwijaya, "Penerapan Metode Winter's Exponential Smoothing Dan Single Moving Average Dalam Sistem Informasi Pengadaan Obat Rumah Sakit," 2010.

[10] A. Nugroho, Penerapan Forecasting Stright Line Method Dalam Pengadaan Stok Barang Mendatang Studi Kasus : Pt. 
JURNAL MEDIA INFORMATIKA BUDIDARMA

Volume 4, Nomor 3, Juli 2020, Page 707-714

ISSN 2614-5278 (media cetak), ISSN 2548-8368 (media online)

Available Online at https://ejurnal.stmik-budidarma.ac.id/index.php/mib

DOI 10.30865/mib.v4i3.2199

Bina Karya Kusuma. Yogyakarta: Penerbit Andi, 2010.

[11] R. Kurniawan, Php \& Mysql Untuk Orang Awam. Palembang: Maxikom, 2010.

[12] M. Sadeli, Jam Belajar Interaktif Visual Basic.Net 2008. Palembang: Maxicom, 2009.

[13] V. R. Sutrisno, "Analisis Forecasting Untuk Data Penjualan Menggunakan Metode Simple Moving Average Dan Single Exponential Smoothing: Studi Kasus Pt Guna Kemas Indah,” Forecast. Penjualan Menggunakan Metod. Mov. Aver. Dan Single Exponential Smoothing, 2013.

[14] Sholiq, Analisa Dan Perancangan Berorientasi Objekno Title. Yogyakarta: Graha Ilmu, 2010. 